\title{
SOME IMPLICATIONS OF ADOPTING NEW CODES - TAX AND FISCAL PROCEDURE - ON SME BUSINESS
}

\author{
Nicoleta ASALOS*, Ioan HURJUI**, Costica ROMAN**, Puiu NISTOREANU*** \\ * "Ovidius" University of Constanta, Romania, \\ ** Stefan cel Mare University, Suceava, Romania, \\ ***The Bucharest University of Economic Studies, Romania \\ nasalos20@gmail.com
}

\begin{abstract}
Given the entry into force of the new Tax Code and of the New Tax Procedure Code in 2016, our approach is aimed at addressing the most important issues of interest to SME entrepreneurship. Obviously, we are referring both to the rules of the respective codes that bring benefits to the shareholders/ entrepreneurs engaged in small business, but also to those designed to displease. Based on the Romanian and foreign literature, in the end, we also propose some solutions in order to improve this situation.
\end{abstract}

Keywords: SME business, taxes,

\section{Introduction}

The status of small and medium contributor to the state budget is of strategic importance. This sector has contributed significantly to economic growth and to the creation of jobs; therefore, it should benefit from state public policies that address smart regulations, a systematic consultation with representative organizations, an attractive fiscal system, increased access to finance and simplified procedures and bureaucracy. By GD no. 859/2014, published in the Official Gazette on $14^{\text {th }}$ October 2014, there was approved the Government Strategy for development of small and medium sized enterprises and for the improvement of the business environment in Romania - Horizon 2020, whose objective was as follows: "Romania - the country with the most attractive business environment for SMEs in the region in 2020". In order to achieve this national objective, Law no. 227/2015 on the Fiscal Code in force from $1^{\text {st }}$ January 2016 brings several changes in taxation.
These fiscal changes concern corporate tax, VAT, microenterprises, income tax, social contributions, local taxes etc. However, this legal document shows a two-step approach regarding the entry into force of certain provisions, so that only some rules apply from $1^{\text {st }}$ January 2017. At the same time, the two pillars of the Romanian tax law, i.e. the Tax Code and the Code of Fiscal Procedure, underwent significant changes in terms of corporate tax, microenterprises and employers, in December 2016, by an emergency ordinance.

\section{SMEs - the engine of the economy}

"The category of Micro, Small and Medium Enterprises (SMEs) is made up of the enterprises that employ less than 250 persons and have an annual net turnover of up to 50 million Euros and/ or total assets of up to 43 million Euros".[1]

The European Union considers that SMEs and entrepreneurship are key elements that support economic development, innovation, 
creation of new jobs and enhancement of social integration. In terms of European policies, the responsible institutions aim at:

- Creating a positive framework for business development (concept Think Small First);

- Promoting entrepreneurship (the framework document Entrepreneurship Action Plan);

- Improving the access to new markets and internationalizing business;

- Facilitating the access to financing;

- Supporting competitiveness and innovation in SMEs;

- Promoting entrepreneurship support[2]

Romania is placed by the European Commission as the leader among the 28 Member States in the field of entrepreneurship, with growth prospects in the number of SMEs by minimum $8.5 \%$ annually[3]. In addition, a number of statistics place Romania above the European average in terms of:

$\square$ the intention to launch a business activity (within 3 years): 31.7\% - Romania; 12.1\% the European average;

$\square$ the opportunities to open a business: $49.75 \%$ - Romania; $47.9 \%$ - the European average;

$\square$ the degree to which the educational curriculum was useful in developing an entrepreneurial mindset: 73 - Romania; 50 - the European average;

$\square$ entrepreneurship is a career option: $73.64 \%$ - Romania; $56.9 \%$ - the European average.

Although the period 2011-2013 was marked by lack of progress, during 2013-2015, the progress was significant, due to the adoption of two strategies in the field, an action plan on entrepreneurship, business environment and SMEs and a government program for 2013-2016. The establishment of a specialized department for SMEs, the business environment and tourism strengthened further progress. As a result, over the past three years, Romania has achieved results above the EU average in terms of facilitating the creation of new enterprises. As far as SMEs are concerned, they have a low innovation level and the knowledge flow between public research and development activities on the one hand, and the business environment, on the other hand, is weak, as confirmed by the fact that Romania is at the bottom of the rank in terms of "Collaborations and entrepreneurship", within the scoreboard.

In 2016, 105,982 new companies were established in Romania, i.e. by $6.35 \%$ less than in 2015; over two thirds of these newly registered entities were limited liability companies. In 2015, 113,167 companies were established, of which 64,417 were limited liability companies and 31,789 were self-employed persons.

In the first two months of 2017, the Romanians founded fewer companies. Only 17,251 new companies were registered in January and February, i.e. by $11.29 \%$ less than those registered last year, during the same period, when there were established 19,447 companies, according to data published by the National Trade Register Office (NTRO) [4].

The number of the limited liability companies registered (which represents the largest share of the total new companies) was only 11,656 , i.e. less than the number of those registered the last year, in the first two months, i.e. 14,282. However, the number of self-employed persons increased from 3,278 (in January-February 2016) to 3,547 (in January-February 2017).

Among cities and regions, the capital remains the leader, with 2,638 new companies registered; however, compared to 2016, we notice a decrease in this number (from 3,213). The next in rank is Cluj (with 941 new companies), Ilfov (with 724), and Timis (with 700). In contrast, the lowest number of companies was registered in Ialomita (130), Teleorman (136), Giurgiu and Calarasi (156) and Covasna (160).

In terms of activities, most registrations were made in wholesale and retail trade, repair of motor vehicles and motorcycles (4,168 registrations), agriculture, forestry and fishing (1,781 registrations) and professional, scientific and technical 
activities (1,608 registrations). According to the NTRO, in the first two months of 2017, the total number of the legally active professionals increased by $2.59 \%$ compared to the same period of the last year, i.e. from $1,167,073$ to $1,197,354$.

Among the action directions included in the governmental program in terms of fiscal matters, there are:

- Supporting and promoting entrepreneurship;

- Access to appropriate finance for SMEs;

- Innovative SMEs;

- Access to markets and the internationalization of SMEs;

- Government reactivity to the needs of SMEs.

The strategic goals by 2020 are:

- 670,000 - number of active SMEs (increase by $41.23 \%$ );

- 36.45 - number of active SMEs per 1,000 inhabitants (increase by $51.50 \%$ )

- 3,233,000 - total number of employees in active SMEs (an increase by $23.23 \%$ )

3. The Tax Code and the Fiscal Procedure Code - between brake and accelerator in SMEs development

The Tax Code of 2016 brings several changes based on the following provisions:

$\square$ VAT decrease in two steps: from $24 \%$ to $20 \%$ from January 2016, and from $20 \%$ to $19 \%$ from $1^{\text {st }}$ January 2017 ;

$\square$ decrease in the tax rate per dividends from $16 \%$ to $5 \%$ from $1^{\text {st }}$ January 2017 ;

$\square$ the tax rate on the microenterprises' income remains at $3 \%$;

start-up companies with at least one employee, established for more than 48 months, have a tax rate of $1 \%$;

self-employed persons also pay social security contributions (the Romanian abbreviation is CAS) of $10.5 \%$ from the actually achieved net income, limited to five average gross monthly salaries.[5]

The conditions for classifying companies in the category of microenterprises were significantly changed in early 2017, with amendments to the Tax Code, by the Emergency Government Ordinance no.
3/2017.

Specifically, the maximum limit up to which a legal person can register as a microenterprise was increased on $6^{\text {th }}$ January 2017 to 500,000 Euros, from 100,000 Euros. Therefore, since February 2017, a legal person is considered a microenterprise if, in the previous financial year, it did not exceed the income of 500,000 Euros, equivalent in RON. In other words, this means that trading companies that have earned an income of up to 500,000 Euros in 2016 must amend their taxation system, as they should pay their income taxes as microenterprises.

Along with the measure of increasing the maximum limit, the GEO no. 3/2017 introduced a tax rate of $1 \%$ for the microenterprises that have at least one employee, employed under a contract of employment, given that, until now, the companies with one employee applied a tax rate of $2 \%$.[6]

Furthermore, the microenterprises with no employees shall apply a tax rate of $3 \%$, i.e. the same as before.

According to the rules in force, employee means a person that is employed full time, under an individual labor contract. However, this condition is considered fulfilled also by the microenterprises that:

- have part-time employees, employed under a part-time individual contract, if the work-load fractions provided therein, taken together, represent the equivalent of a fulltime position;

- have signed management contracts or mandates, under the law, if their remuneration is at least at the level of the guaranteed minimum national gross salary As far as microenterprises are concerned, the cited document provides for the reduction of the maximum limit of the founding capital, in terms of which the tax regime for micro-enterprises may be applicable or not. Specifically, the maximum limit of the share capital wherefore the corporate tax payment may be chosen, instead of the tax on the microenterprises' income, has been reduced 
from 25,000 Euros (about 112,000 RON) to 45,000 RON (about 10,000 Euros).

Under Article 47 of the Tax Code, a microenterprise is, in 2017, that legal entity that has met cumulatively at $31^{\text {st }}$ December 2016, the following conditions:

- has earned income from activities carried out in fields other than banking, insurance and reinsurance, capital market, gambling or exploration, development and exploitation of oil and natural gas deposits;

- has earned income from activities carried out in fields other than consultancy and management, in a share greater than $80 \%$ of total revenue;

- has earned income that did not exceed the equivalent in RON of 500,000 Euros (the newly introduced maximum limit);

- the share capital was held by persons other than state and local authorities;

- it is not under dissolution by liquidation, registered in the Trade Register or in courts.

Moreover, if during a fiscal year a microenterprise earns an income that exceeds 500,000 Euros or if the share of the revenue from consulting and management activities in total revenue is over $20 \%$, inclusively, the entity shall pay a corporate tax of $16 \%$. The calculation and payment of corporate taxes are made as from the quarter when any of the previously mentioned limits were exceeded, taking into account the revenues and the expenditures incurred as from the respective quarter (i.e. when any of these limits were exceeded).

The statement whereby a taxpayer was assessed by tax officials in terms of the ability to carry out economic activities in the field of VAT was removed from $1^{\text {st }}$ February 2017. Over time, about 15,000 companies have been refused the registration because of this statement. In addition, from this date, the companies operating in research and innovation fields shall be exempted from corporate taxes for a period of 10 years.

\section{Conclusions}

The decrease in the number of the companies registered at the beginning of this year was caused by issues such as instability and lack of predictability in society, lack of prevention in the control activities carried out by state institutions, the poor accessibility of national funds and the lack of access to European funds. Bureaucracy, underdeveloped infrastructure and the low levels of entrepreneurial education are as many obstacles to innovative entrepreneurship and to the creation and development of enterprises in the technological sector. SMEs have a low innovation level and knowledge flow between public R\&D activities and the business environment. Many of the tax changes affect SMEs, some of which are now listed among microenterprises, under a different taxation regime.

\section{References}

[1] Extract from Article 2 of the Annex of Recommendation 2003/361/EC1 transposed into national law by GO no.27/2006 - Official Gazette no.88/31.01.2006 approved by Law no.175/2006 - Official Gazette no. 438/22.05.2006

[2] Your Europe Business Portal, Enterprise Europe Network, SME Internationalization Portal, Access to Finance

[3] Small Business Act Report, published in 2015

[4] http://www.onrc.ro/index.php/ro/statistici

[5] https://static.anaf.ro/static/10/Anaf/legislatie/Cod_fiscal_norme_2016.htm

[6] http://lege5.ro/Gratuit/ge2daojzgeyq/ordonanta-de-urgenta-nr-3-2017-pentru-modificareasi-completarea-legii-nr-227-2015-privind-codul-fiscal 